\title{
Optimal PID controller of a brushless DC motor using genetic algorithm
}

\author{
Muhammed A.Ibrahim ${ }^{1}$, Ausama Kh. Mahmood ${ }^{2}$, Nashwan Saleh Sultan ${ }^{3}$ \\ ${ }^{1}$ System and Control Department, Ninevah University, Iraq \\ ${ }^{2}$ Electrical Power Department-Technical Institute in Mosul, Northern Technical University, Iraq \\ ${ }^{3}$ Power Technical Engineering Department, Northern Technical University, Iraq
}

\begin{tabular}{l}
\hline \hline Article Info \\
\hline Article history: \\
Received Oct 16, 2018 \\
Revised Nov 19, 2018 \\
Accepted Feb 11, 2019
\end{tabular}

Keywords:

Brushless DC motor Genetic Algorithm. Integral Absolute Error (IAE) Integral Squared Error (ISE) PID Controllers

\begin{abstract}
Brushless DC (BLDC) motor is commonly employed for many industrial applications due to their high torque and efficiency. This article produces an optimal designed controller of Brushless DC motor speed control depending on the genetic algorithm (GA). The optimization method is used for searching of the ideal Proportional-Integral-Derivative (PID) factors. The controller design methods of brushless DC motor includes three kinds: trial and error PID design, auto-tuning PID design and genetic algorithm based controller design. A PID controller is utilizing by conducted Integral absolute error criterion (IAE) and integral squared error (ISE) error criterion for BLDC motor control system. A GA-PID controller is designed to enhance the system performance by means of genetic algorithm. PID controller coefficients $\left(K_{p}, K_{i}\right.$ and $\left.K_{d}\right)$ are calculated by GA to produce optimal PID as hybrid PID with GA controller. The closed loop speed response of PID controller is experimented for IAE and ISE error criteria. The suggested controller GA_PID is planned, modeled and simulated by MATLAB/ software program. A comparison output system performance monitored for every controller schemes. The results display that the time characteristics performance of GA-PID controller based on ISE objective function has the optimal performance (rise time, settling time, percentage overshoot) with other techniques.
\end{abstract}

Copyright @ 2019 Institute of Advanced Engineering and Science. All rights reserved.

\section{Corresponding Author:}

Nashwan S. Sultan,

Dep. of Power Technical Engineering, Technical College of Engineering,

Northern Technical University,

Mosul/ Iraq.

Email: sultan_nashwn@yahoo.com,nashwan.saleh@ntu.edu.iq

\section{INTRODUCTION}

The BLDC motors are commonly used in industrial applications and instrumentations more than conventional DC motor due to attractive features such as: high efficiency, high torque, great speed, small noise, minor volume and extended life. The BLDC motors do not have brushes like DC motor therefore no sparks during operation. This allows using the motor in hazardous areas. As it is shown in Figure 1 simple cross section BLDC motor containing stator that carries windings. While the rotor contains permanent magnets for arrangement two magnetic pairs of pole. The stator windings are divided in two kinds: sinusoidal and trapezoidal. These two kinds shape the form of the back electromotive force (BEMF) indication. The form of BEMF is adjusted by dissimilar coil inter - connections and the space of the air gap [2]. In addition to BEMF, the phase current also tracks a sinusoidal and trapezoidal form. A sinusoidal motor type produces flatter electromagnetic torque than other trapezoidal motor type. However, a BLDC motor works easily through trapezoidal stator windings. While the conventional DC motor produces flux when current pass 
through the stator winding, but the BLDC motor uses permanent magnetic to provide the necessary air gab flux[3].

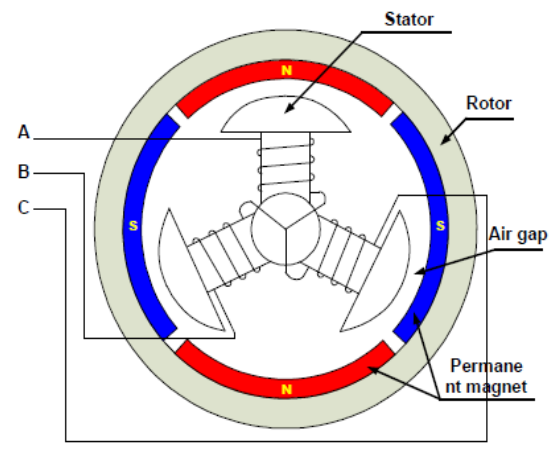

Figure 1. BDCM simple cross section.

The authors introduce a renewable energy as photovoltaic cell source to feed the BLDC during the boost converter and three phase inverter. This green electrical energy source with MPPT method for BLDC motor was employed and confirmed with MATLAB simulation. This motor is operating with photovoltaic power source as well as energy battery source. The Coupled inductor of the boost converter with variable duty cycle of the inserted converter was merged. The speed controller was designed to advance the BLDC motor performance [3]. In [4], BLDC motor digital control with PID and Hybrid Fuzzy-PID for steady state operation and many different speeds (Dynamic State). Result fuzzy-PID controller has more efficiency than PID controller (better performance). The BLDC motor is controlled by designing two controller types' fuzzy logic and PI controllers. These controllers controlled the speed of BLDC motor. The system output performance results are compared with these controller types. The designed FLC is best than PI controller for the motor speed through reducing overshoot, computational time and lower error [5]. In [6], The controller PID and bacterial foraging(BF) - particle swarm optimization(PSO) algorithm (combining PSO and BF) was used with IAE, ISE, MSE and IATE error criteria, Relying on their results BF-PSO PID controller improves the performance better than PID controller. The BLDC motor speed was controlled by designing the Single Input Fuzzy PI Controller. The simplified FLC was used with one control input. The SIFPIC are solves many problems made by classical FLC for example long proposal cycle, factors for tuning and difficulty of process to implement at the control. The simulation method with the SIFPIC, classical FLC, and discrete PI controller are operated to regulate and control this motor. The comparison results for these controllers that produce the SIFPIC controller is the better than others [7]. In [8], the PID controller gains are obtained through conventional methods of Ziegler-Nicholas (ZN), Cohen Coon (CC) and Amstron-Hagglund (AH) using Fractional Order PID to control the speed and improvement in transient performance. The BLDC motor with three classical sensors is driven and fed by photovoltaic energy source through step up DC to DC converter operating in the great voltage gain with three phase inverter. This system is verified for adjustable incremental motor speed with static torque and adjustable decremented motor speed with static torque working settings [9].

BLDC motor Speed and torque control is extremely significant. Speed control is required to adjustment the input electric power of the motor to reach speed which is needed. Moreover speed control is important when the motor speed stable and accurate in sensitive application. Various approaches PID controller is designed for BLDC motor were employed with respect to high performance time characteristics requirements. Early conventional approaches are utilized for PID controller to control the rotation of the motor for aim that requires low accuracy such as trial and error and MATLAB tuner application. For applications where the change of speed and torque is an important factor, it is very necessary to have an effective and precise controller strategy. Now a days, intelligent techniques like particle swarm optimization (PSO), bacterial foraging (BF) and genetic algorithm (GA) methodology are used to obtain a better controller performance to control the electric machines when the optimality required in sensitive applications for type of BLDC motors. In the current article the optimal PID controller was designed for BLDC motor control system. This method is used based on the IAE and ISE error criteria minimization based on genetic algorithm techniques to achieve optimal PID controller factors for result enhancements and system performance improvement.

Optimal PID controller of a brushless DC motor using genetic algorithm (Muhammed A.Ibrahim) 


\section{RESEARCH METHOD}

The major difference between the traditional DC motor and BLDC motor is increasing of parts complexity that impact on the BLDC motor general results. The inductive and resistive shares of the BLDC motor configuration become pretentious when there's phase alteration. Figure 2 shows the symmetrical 3phase "wye" internal connection of this motor. The BLDC motor mathematical structure was created from the typical DC motor mathematical model [5].
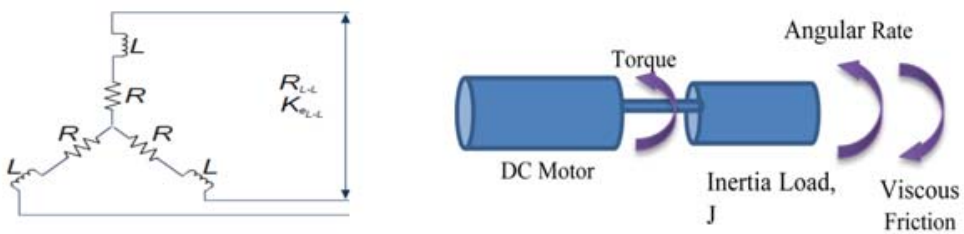

Figure 2. BLDC motor model.

BLDC motor is like conventional DC motor except there is three phases in BLDC motor, the BLDC motor output speed is regulated through ways of a three - phase pulse-width modulation inverter. This motor dynamic features is like to permanent magnet DC motor. The BLDC motor equations can be expressed by (1)-(5) [10]

$$
\begin{aligned}
& v_{a p p}(t)=L \frac{d i(t)}{d t}+R * i(t)+v_{e m f}(t) \\
& V_{e m f}=k_{b} * w(t) \\
& T(t)=K_{t} * i(t) \\
& T(t)=J \frac{d w(t)}{d t}+D * w(t)
\end{aligned}
$$

where:

$v_{\text {app }}(t)$ : applied voltage

$w(t)$ : Motor speed

$V_{\text {emf }}$ : Back electromotive force

$i(t)$ :he moto current

L: The inductance of stator

$\mathrm{T}$ : The motor torque

D: Viscous coefficient

$\mathrm{J}$ : Moment of inertia

$\mathrm{Kb}$ : Back electromotive force

The BLDC motor transfer function with control system is calculated:

$$
G(s)=\frac{w(s)}{V(s)}=\frac{k_{t}}{L * J * s^{2}+(L D+R J) * s+k_{t} k_{b}}
$$

The BLDC motor mathematical model is calculated depending on the chosen value of motor parameters from which are represented in Table 1.

Table 1. Parameters values of the studied motor

\begin{tabular}{lc}
\hline Parameters & Values \\
\hline Stator resistance ( R) & $21.2 \Omega$ \\
Inductance of the stator(L) & $0.052 \mathrm{H}$ \\
Motor torque constant (Kt) & $0.1433 \mathrm{Kg}-\mathrm{m} / \mathrm{A}$ \\
Back electromotive force constant $(\mathrm{Kb})$ & $0.0419 \mathrm{~V} / \mathrm{rad} / \mathrm{S}$ \\
Moment of inertia (J) & $1 * 10^{-5} \mathrm{Kgm} \mathrm{s} / \mathrm{rad}$ \\
Viscous coefficient(D) & $1 * 10^{-4} \mathrm{~kg}-\mathrm{m} \mathrm{s} / \mathrm{rad}$ \\
\hline
\end{tabular}

Int J Pow Elec \& Dri Syst, Vol. 10, No. 2, June 2019 : 822 - 830 


\section{PID CONTROLLER}

The PID (Proportional, Integral and Deferential) controller design based on Ziegler-Nichols method depends on trial and error to tuning the parameters $\left(K_{p}, K_{i}\right.$ and $\left.K_{d}\right)$. This method is performed employing the BLDC motor model of open loop system and then finding the required values of motor parameter necessary for calculating PID factors gain values in order to get best response [9].

However, conventional PID controller was worked to control and improve the speed-torque of BDCM motor since PID controller has advantages like: simple and easy to use, stable, easy to adjustable and high reliability The conventional methods of PID tuning are not reliable for real time response. Figure 3 shows the BDCM with PID controller system block diagram. The control function expressed as [11].

$$
\mathrm{u}(\mathrm{t})=\mathrm{k}_{\mathrm{p}}+\frac{\mathrm{k}_{\mathrm{i}}}{\mathrm{s}}+\mathrm{k}_{\mathrm{d}} \mathrm{s}
$$

Where:

$K_{p}$, and are the proportional, Integral and derivative controller gain values of PID controller.

PID Tuning Implementation: There are many method s to tuning conventional PID, in this paper, two methods were chosen for tunnig:

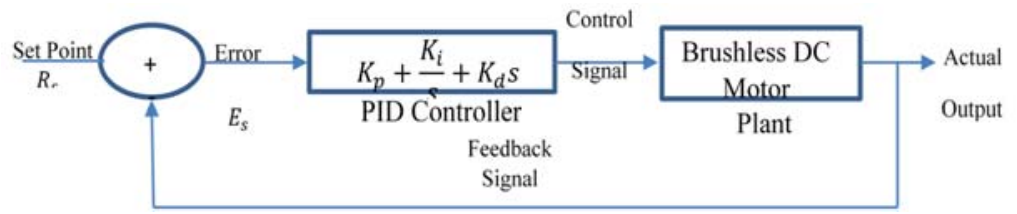

Figure 3. BLDC motor with PID controller system block diagram

\subsection{Tarial and error tunning}

In this method, $\mathrm{Kp}, \mathrm{Ki}$ and $\mathrm{Kd}$ values are selected based on the designer's experience, from this method the obtained coeffecients values of PID gains are: $\mathrm{Kp}=800, \mathrm{Ki}=290, \mathrm{Kd}=0.039$

The response of BDCM using traial and error and time characterstics is shown in Figure 4

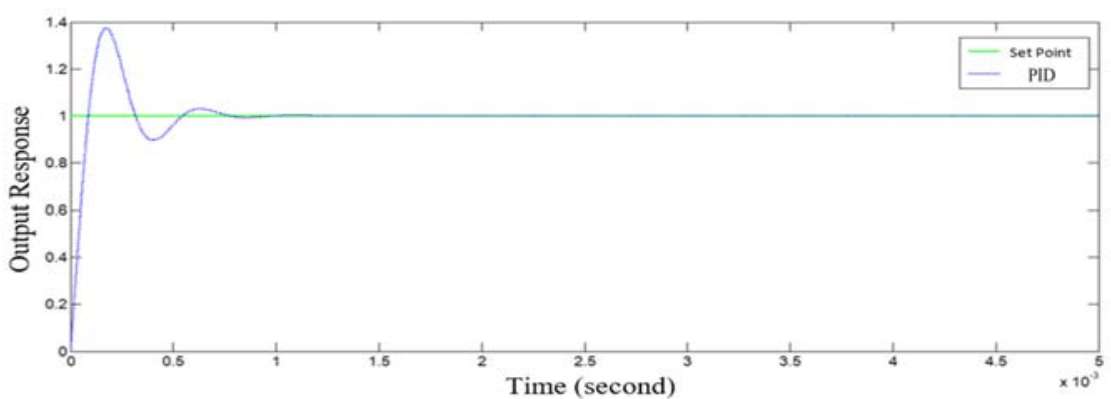

Figure 4. Step response of trial and error for BLDC motor system

\subsection{MATALB PID tunner app.}

The Kp,Ki and Kd values are achieved by using MATLAB PID Tuner Application in MATALB R2017a software as shown below: $\mathrm{Kp}=700, \mathrm{Ki}=360, \mathrm{Kd}=0.09$. Figure 5.

The response of BDCM using MATLAB Tunner trail and error and time characterstics are shown in 


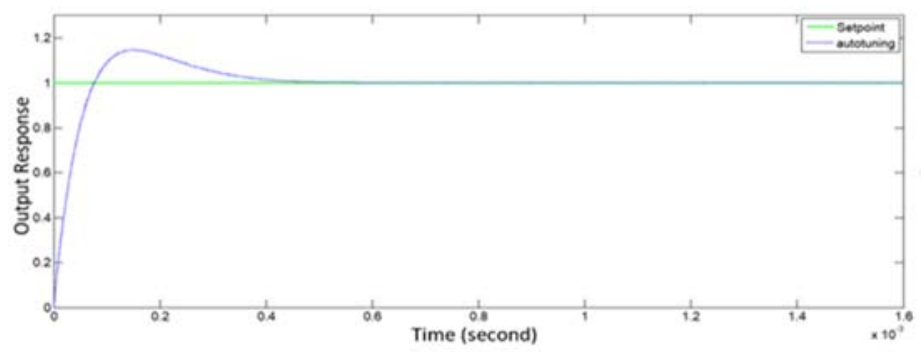

Figure 5. Step response of auto tuning for BLDC motor system.

\section{GENETIC ALGORITHM TUINNING PID COTROLLER}

Genetic algorithm is the major categoy of evolutionary algorithms (EA) that creates resolutions to optimization difficulties retaining methods stimulated by usual developments such as: selection, inheritance, mutation and crossing. GA is operated to decide on optimizing the rates of PID controller gains for the selected BLDC motor system. The controller is proposed for to reduce the error decrease of the output response with regand to the orientation signal [12]. The error is computed equally the performance table, achieved by reducing the error among the units step of input response. The physiognomies for the wanted performance are typically stated in relations of time field amounts. The configuration of the genetic algorithm modification PID controller factors are shown in the Figure 6.

The performance of control system is measured equally to optimum. If the parameters values of PID controller are selected such the performance table is lowest. Integral squared error (ISE) and integral absolute - error criterion (IAE) are selected as objective function in the controller plan technique. The genetic software design is used to mitigate the zones. The error criteria IAE and ISE formulas are as follows [13]:

$$
\begin{aligned}
& I A E=\int_{0}^{T s s} a b s(e(t)) d t \\
& I S E=\int_{0}^{T s s} e(t)^{2} d t
\end{aligned}
$$
Figure 7.

The proposed flowchart below illustrations the full procedure of GA evaluation more obviously in

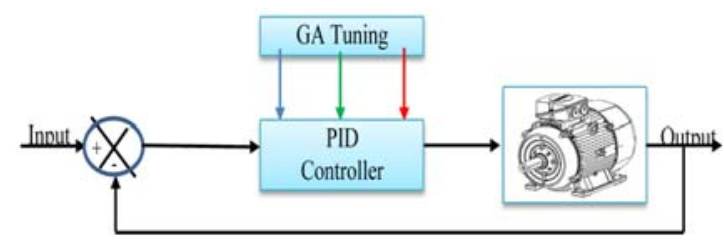

Figure 6. Optimal PID Controller configurations. 


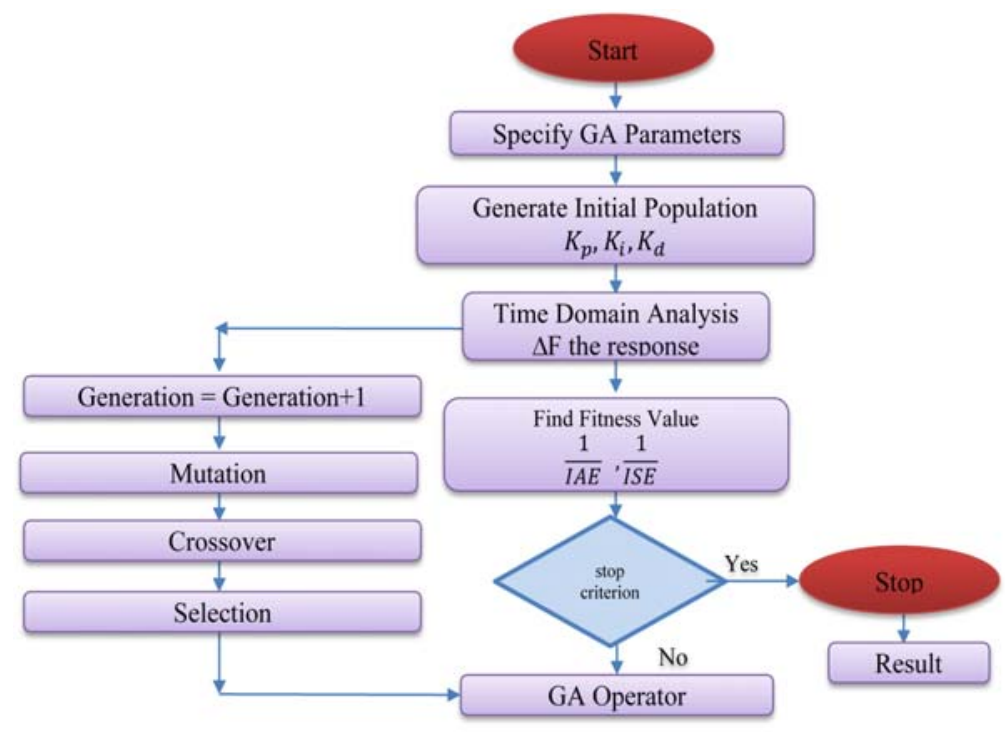

Figure 7. Proposed genetic algorithm process design flowchart. Area of error for the system response

Proposed genetic algorithm process designed in MATLAB /SOFTWARE is shortened in the following steps.

1-Specify the algorithm parameters, the major characteristics of the considered optimizer are as outlines in Table 2.

Table 2. Parameters of GA

\begin{tabular}{ll}
\hline $\begin{array}{l}\text { Fitness function } \\
\text { (performance index) }\end{array}$ & 1/IAE \& 1/ISE \\
\hline Selection method & Roullete \\
Generation size & 40 \\
Population size & 30 \\
Fitness scaling & Proportional \\
Crossover method & Arithmetic crossover \\
Crossover probability & $90 \%$ \\
Mutation probability & $2 \%$ \\
Mutation method & Uniform mutation \\
Stalled generation & 20 \\
\hline
\end{tabular}

2-Random generation of PID parameters ( $\mathrm{Kp}, \mathrm{Ki}, \mathrm{Kd}$ ).represented by matrix of suitable solution for each available set . Population (P) matrix as shown in equation (10)

$$
\text { population }=\begin{array}{lll}
k p 1 & k i 1 & k d 1 \\
k p 2 & k i 2 & k d 2 \\
k p n & k i n & k d n
\end{array}
$$

Where n number of population.

3- Calculating of the fitness value for every set of solution, the fitness function in proposed algorithm is given in equation (8) \& equation (9). This applied to minimization.

4- Selecting of limited population with greater performance.

5- Compositing of novel set of solution (new kp ki kd) from finest solution in preceding loops.

6- Using genetic operators function (crossover \& mutation).

7-Repeating previous steps (from 3 -6) till obtaining optimal PID controller coefficients.

The table 3 reviews the optimal gain values of PID controller attained through using genetic algorithm for different error criteria. The response of GA_PID of both error criteria is shown in Figure 8. 
Table 3. Gains of PID controller enhanced by genetic algorithm

\begin{tabular}{ccc}
\hline parameters & IAE & ISE \\
\hline $\mathrm{Kp}$ & 389.625 & 463.765 \\
$\mathrm{Ki}$ & 499.822 & 499.853 \\
$\mathrm{Kd}$ & 15.597 & 174.886 \\
\hline
\end{tabular}

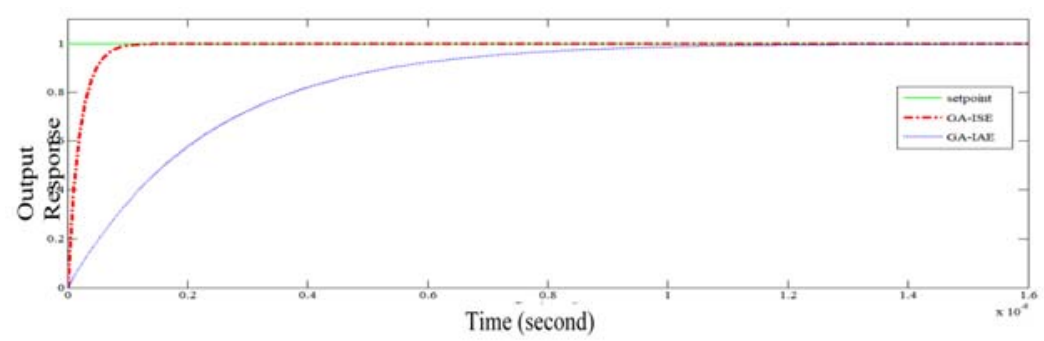

Figure 8. Step response of GA-PID for BLDC motor system.

\section{RESULTS AND ANALYSIS}

The achievement of conventional PID controller is not getting the perfect results for high performance control system design of BLDC motor system .Similarly the appropriate optimized coefficient values of controller are gotten by the employment of genetic algorithm based PID controller. A simulation program is planned to associate the steady and dynamic performances for the certain BLDC motor control system. The time response characteristics of different controller are presented in Figure 9.

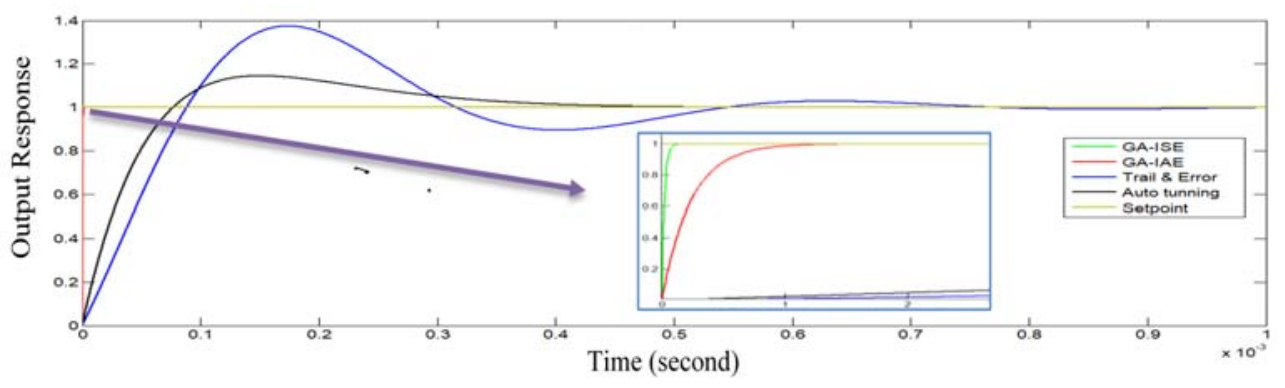

Figure 9. Step responses for PID/GA, trial \& error and conational PID controllers

To calculate the performance and steadiness of the controlled system a series of dimension are accomplished. The rise time, steady-state error, maximum overshoot and settling time are chosen. This transient parameter are obtained and shown in Table 4.

Table 4. Result of time response characteristics

\begin{tabular}{ccccc}
\hline parameters & Trail \& error & MATLAB tuner & GA-IAE & GA-ISE \\
\hline Rise time(s) & $6.87 \mathrm{e}-5$ & $5.64 \mathrm{e}-5$ & $5.11 \mathrm{e}-7$ & $4.56 \mathrm{e}-8$ \\
Settling time(s) & 0.000692 & 0.000375 & $9.11 \mathrm{e}-7$ & $8.12 \mathrm{e}-8$ \\
Overshoot $(\%)$ & 37.4 & 14.5 & 0 & 0 \\
Peak & 3.74 & 1.44 & 1 & 1 \\
Steady state error & 0 & 0 & 0 & 0 \\
\hline
\end{tabular}

Several schemes controller design of presenting the response information are attempted to find an optimum method for use to drive BLDC motor. From Figure 10, Comparing the performance it is remarkably obvious the maximum overshoot of the system in conventional controller is much bigger than

Int J Pow Elec \& Dri Syst, Vol. 10, No. 2, June 2019: $822-830$ 
from GA- PID .The GA-PID controller gives less settling time and rise time compared with classical PID controller. Also in evaluation with the other controllers the achieved findings present that the GA-PID controller has the optimum improvement in the system performance.

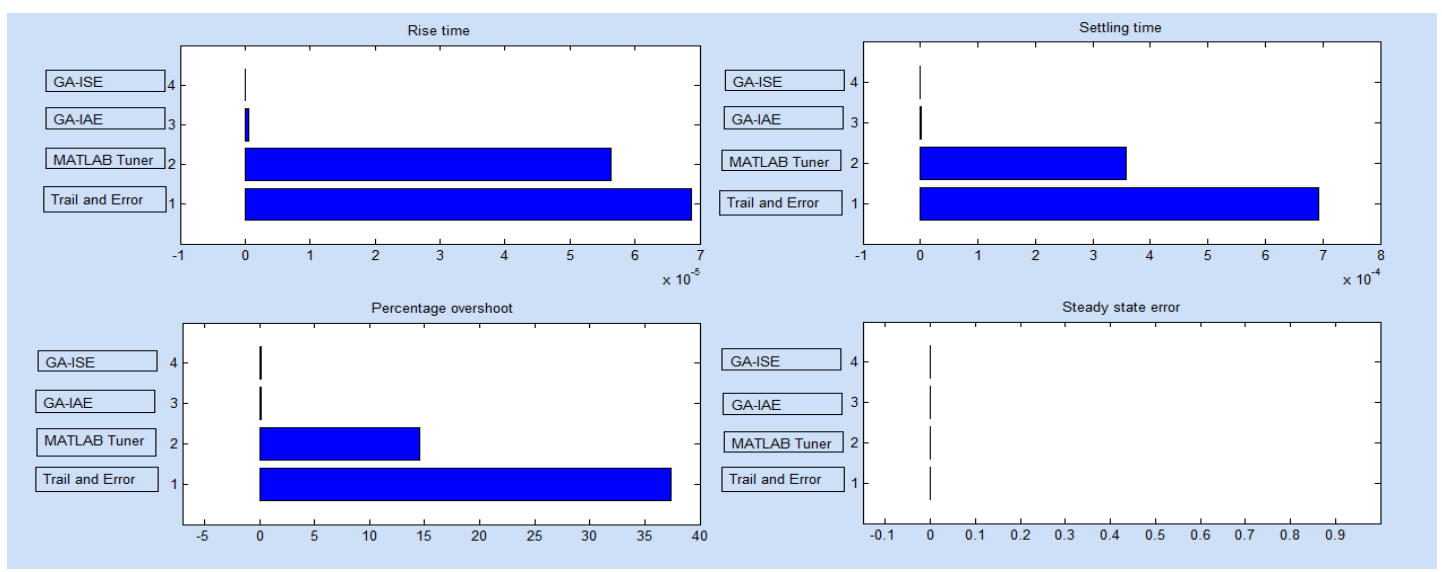

Figure 10. Controllers performance evaluation analysis

\section{CONCLUSION}

In this study, the designed PID for BLDC motor control system including enhancement by GA is proposed. The proposed controller has much better time response characteristics compared with the conventional technique. The conventional method for tuning PID parameters is informal in computing. It is suitable for providing us with the initial point of the PID controller coefficient values. Whereas the genetic algorithm designed PID is abundant finest in relations to the rise time, settling time and percentage overshoot than the conventional technique. In GA_PID designed two performances index have used IAE and ISE in error computation. The ISE criterion easy to calculate and it admits discriminating overdamped from underdamped system. IAE makes slower response than ISE outputs but without a big oscillation over time. Consequently this proposed regulator (GA- ISE optimizer) can be employed to drive a BLDC motor for sensitive applications.

\section{REFERENCES}

[1] Ahmed, Ahmed M., et al. "Brushless DC motor speed control using both PI controller and fuzzy PI controller” International Journal of Computer Applications, Vol. 109(10), pp. 29-35, 2015.

[2] Zhao, Jian, and Yangwei Yu. "Brushless DC motor fundamentals application note "MPS, Futur. Analog IC Technol, pp. 7-8, 2011.

[3] V. Senthil Nayagam and L. Premalatha."Green Energy Based Coupled Inductor Interleaved Converter with MPPT Technique for BLDC Application." International Journal of Power Electronics and Drive System (IJPEDS), Vol. 9, No. 4, pp. 1725-1732, December 2018.

[4] Soni, Yogendra Kumar, and Rajesh Bhatt. "BF-PSO optimized PID controller design using ISE, IAE, IATE and MSE error criteria“, International Journal of Advanced Research in Computer Engineering and Technology. Vol. 2. No. 7, pp. 2333-2336, 2013.

[5] Akram H. Ahmed, Abd El Samie B. Kotb and Ayman M.Ali, "Comparison between Fuzzy Logic and PI Control for the Speed of BLDC Motor". International Journal of Power Electronics and Drive System (IJPEDS), Vol. 9, No. 3, pp. 1116 1123, September 2018.

[6] Soni, Yogendra Kumar, and Rajesh Bhatt. "BF-PSO optimized PID controller design using ISE, IAE, IATE and MSE error criteria." International Journal of Advanced Research in Computer Engineering and Technology. Vol 2 no 7, pp. 2333-2336, 2013.

[7] N. N. Baharudin and S. M. Ayob, "Brushless DC Motor Speed Control Using Single Input Fuzzy PI Controller". International Journal of Power Electronics and Drive System (IJPEDS), Vol. 9, No. 4, pp. 1952 1966, December 2018.

[8] Khubalkar, S. W., et al. "Design and tuning of fractional order PID controller for speed control of permanent magnet brushless DC motor", Control, Measurement and Instrumentation (CMI), 2016 IEEE First International Conference on. IEEE, 2016. 
[9] G.G.Raja Sekhar and Basavaraja Banakara, "Performance of Brushless DC Drive with Single Current Sensor Fed from PV with High Voltage-Gain DC-DC Converter". International Journal of Power Electronics and Drive System (IJPEDS), Vol. 9, No. 1, pp. 33 45, March 2018.

[10] Nasri, Mehdi, Hossein Nezamabadi-Pour, and Malihe Maghfoori. "A PSO-based optimum design of PID controller for a linear brushless DC motor” World Academy of Science, Engineering and Technology, vol. 26, no.40, pp. 211$215,2007$.

[11] Pothorajoo, Satishrao, and Hamdan Daniyal. "PID bidirectional speed controller for BLDC with seamless speed reversal using Direct Commutation Switching Scheme." Control and System Graduate Research Colloquium (ICSGRC), 2017 IEEE 8th. IEEE, 2017.

[12] S Dawood, Younis, Ali K Mahmood, and Muhammed A Ibrahim. "Comparison of PID, GA and Fuzzy Logic Controllers for Cruise Control System", International Journal of Computing and Digital Systems, vol 7, no 05, pp. 311-319.; 2018.

[13] Krohling, Renato A., and Joost P. Rey. "Design of optimal disturbance rejection PID controllers using genetic algorithms", IEEE Transactions on Evolutionary computation, Vol 5 no 1, pp. 78-82, 2001.

\section{BIOGRAPHIES OF AUTHORS}
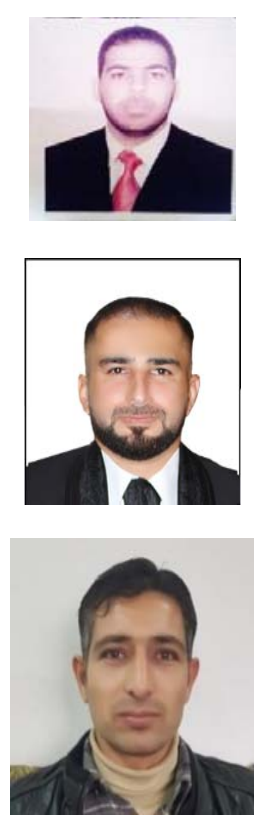

Muhammed A.Ibrahim. B.Sc in Power Technical Engineering/ Northern Technical UniversityIraq-Mosul in 2011 with grade very Good with Ranked first. MSc in Electrical Engineering /Control Engineering from Electrical Eng. Dept. / College of Engineering /University of Mosul in 2013 with grade very Good. Currently he is an assisting lecturer at the Department System and Control /Electronics Engineering / Ninevah University. current research interests include linear and nonlinear systems optimization, Machines and drives.

Ausama Kh. Mahmood. B.Sc in Power Technical Engineering/ Northern Technical UniversityIraq-Mosul in 2011 with grade very Good. MSc in Electrical Engineering /Power Electronic Engineering from Electrical Eng. Dept./ Engineering College / Mosul University in 2014 with grade Good. Currently he is an assisting lecturer at Electrical Power Department - Technical Institute in Mosul/Northen Technical University

Nashwan S.Sultan. B.Sc in Power Technical Engineering/ Northern Technical University- IraqMosul in 2008 with grade very Good with Ranked first. MSc in Electrical Engineering /Control Engineering from Electrical Eng. Dept./College of Engineering/University of Mosul in 2013 with grade very Good. Currently he is an assisting lecturer at the Department Power Technical Engineering/ Engineering Technical College/Mosul. 